\title{
Experiences and Challenges Perceived by Indonesian EFL Teachers as Non-Native English Speaker Teachers (NNESTs) in Thailand
}

\author{
Vincentia Aprilla Putri \\ Universitas Negeri Malang \\ vincentiaaprillaputri@gmail.com
}

\begin{abstract}
This study investigated the experiences and challenges perceived by Indonesian EFL teachers as the NNESTs in Thailand. The study used a questionnaire and interviews to collect primary data from seventeen Indonesian EFL teachers in Thailand. The study discovered that most of the Indonesian EFL teachers are eager to teach English in Thailand to have teaching experience abroad, to improve their English skills, and to earn higher salaries. Besides, the Indonesian EFL teachers did not find difficulties in adapting to the new cultures in Thailand, even though adjusting to the teaching environment became a challenge. Moreover, third, the Indonesian EFL teachers were treated equally as the NESTs, although their salaries were lower than those of NESTs. Lastly, the study reported issues in English classes, such as students' motivations, linguistic gaps, and plagiarisms, which trigger the creativity of Indonesian EFL teachers in English classes.
\end{abstract}

ARTICLE HISTORY

Received 3 February 2020

Accepted 10 June 2020

\section{KEYWORDS}

challenges; experiences; Indonesian EFL teachers;

NESTs; NNESTs

\section{Introduction}

The presence of native-English speaker teachers (NESTs) and non-native English speaker teachers (NNESTs) remain central to everyday English language teaching discourse and practice in many parts of the world (Benson, 2012). For instance, in the context of Thailand, as a response to the low level of English proficiency (Hickey, 2014), the country tries to improve the English language abilities of students through the enhancement of language education and bilingual programs (Tanielian, 2014). Therefore, many schools have opened a vast opportunity for foreigners to teach English at private and public schools in the country (Hickey, 2014).

Among the foreign teachers teaching in Thailand, native-English speaker teachers (NESTs) from English-speaking countries such as the United States, United Kingdom, Canada, Australia, and New Zealand are still preferably hired in Thailand 
(Hickey, 2014). Nevertheless, the non-native English speaker teachers (NNESTs) from other countries such as Kenya, Cameroon, the Philippines, and even Indonesia are still welcomed to teach English in numerous schools in Thailand. Considering this, there are possibilities of challenges faced by NNESTs for teaching in a society where the presence of native English speaker teachers (NESTs) is highly demanded.

Studies on the experiences, issues, and challenges of the non-native English speaker teachers (NNESTs) have been conducted mostly in the contexts of Thailand and Hong Kong. Those studies revealed that there was a dichotomy between NESTs and NNESTs in terms of salaries and workplace discriminations (Hickey, 2014; Ulla, 2019). The study conducted by Ulla (2019) presented the Filipino EFL teachers' perceptions of issues and challenges as NNESTs in Bangkok. The study revealed that the participants held a positive view of being NNESTs, teaching EFL students in Bangkok. Moreover, NNESTs played an equally important role as NESTs in the English language improvement in the ASEAN region. Besides, another study conducted by Sung (2012) discovered that the dichotomy between NESTs and NNESTs in terms of teaching skills influenced the perceptions of secondary school students in Hong Kong.

Although nowadays, the number of Indonesian teachers teaching English as a Foreign Language (EFL) in Thailand has been increasing, the study which focuses on the Indonesian EFL teachers as NNESTs in Thailand has not been widely conducted. Thus, this current study seeks to investigate the experiences and challenges perceived by Indonesian EFL teachers as NNESTs in Thailand. The different experiences and challenges perceived by Indonesian EFL teachers in Thailand are expected to be advantageous to foreign teachers, especially the NNESTs who are interested in teaching English in Thailand. Therefore, the present study intends to investigate the experiences and challenges perceived by Indonesian EFL teachers as NNESTs in Thailand.

\section{Literature Review}

\section{English Language in Thailand}

English has been a part of the curriculum and becomes a compulsory subject from primary school onward in Thailand (Chamcharatsiri, 2010). The presence of English subject in formal schools has been for around 150 years since King Rama IV ordered that English be a part of the training for royal children (Grubbs, Chaengploy, $\&$ Worawong, 2009). Since then, Thai people consider English as a foreign language, which is mainly used for business, tourism, and educational purposes. Thus, students who want to get a good position in large corporations push themselves to learn and use English accurately and fluently (Chamcharatsiri, 2010) However, numerous Thai students still claim that English subject is monotonous and stressful. They do not even find reasons to learn English (Chamcharatsiri, 2010). 
A study by (Grubbs et al., 2009) on students at three traditional university campuses and four Rajabhat universities in Central-Western Thailand revealed that students had positive views on English. Most students thought that English was important and beneficial for their academic pursuits. However, they did not think highly of their abilities. This point of view was in line with other studies that revealed the difficulty in English-learning among Thai students. The challenge in mastering English was shown by the English test results of Thai national testing that downgraded at least from 2000 to 2008 (OECD-UNESCO, 2016).

The national language spoken by students undeniably influences the English proficiency of Thai students. The Thai language is somehow different from English in terms of phonological, grammatical, and lexical items. In terms of grammar, the Thai language does not apply the verb as a tense marker. It uses adverbs or nouns signifying time, which is placed in the sentence-initial position. In the Thai language, the participant precedes the verb; the object follows the verb, forming Subject-VerbObject word order without the presence of the semantic role of a noun phrase. Besides, in the Thai language, verbs are not only to represent action and its objectives but also a cause and its result, and action and its evaluation. Moreover, causative and passive constructions are part of verb serialization (Minegishi, 2011). In terms of speech or expression, some speech events in Thai and English are different. For instance, in saying apology and thanks. In English, there are many ways to apologize, whereas Thai people would say sorry in a single form. Besides, when the British may have several direct strategies to express thanks, Thai people have less explicit strategies (Intachakra, 2004).

\section{Native English Speaker-Teachers (NNEST) and Non-native English Speaker- Teachers (NNESTS)}

The success of English language teaching (ELT) depends not on whether the teacher is a native speaker of English or not, but on the particular teaching context (Ulla, 2019). This statement is in line with (Brown \& Lee, 2015), who states that native English-speaking teachers (NESTs) are not better than non-native English-speaking teachers (NNESTs) by virtue of their native language background. The most important qualification for a teaching position is training and experience in teaching languages (p.165). Hence, not only native English-speaking teachers (NESTs) who have the privilege of teaching English (Methanonppkakhun \& Deocampo, 2016)

Despite the fact that both native English-speaking teachers (NESTs) and nonnative English-speaking teachers (NNESTs) have an equal chance to teach English, more NNESTs are teaching English in some parts of Asia, especially in the ASEAN region (Waterworth, 2016). In the Asia context, the issue where native speakers are often the ideal model and that American English is the preferred variety is particularly noticeable (Young \& Walsh, 2010). The native English-speaking teachers (NESTs) are also often preferred over non-native English-speaking teachers (NNESTs) (Braine, 
2010). Students' preference for NESTs has been presented in a number of studies (Songsirisak, 2017; Walkinshaw \& Duong, 2012; Walkinshaw \& Oanh, 2014). Hence, there are cases of discrimination against NNESTs that use students' preferences as the common excuse for the discrimination against NNESTs (Braine, 2010; Sung, 2012).

Nevertheless, several studies have started to question whether, in the ELT profession, the ideal teacher is only the NEST. A study conducted by Walkinshaw \& Oanh (2014) found out that there were benefits of learning with both NESTs and nonNESTs at tertiary institutions in Vietnam and Japan. However, non-native Englishspeaking teachers were second-class educators and inherently inferior to nativespeaker teachers. This study was similar to the study conducted by Sung (2012), which revealed that NNESTs should stand the same chance of becoming successful teachers of English as NESTs because both NESTs and NNESTs showed excellent abilities in teaching particular English subjects. The NESTs showed outstanding skill in teaching grammar. They had a deep declarative knowledge of the grammatical rules in English. They were also able to show empathy to the needs and problems of the students.

In contrast, the NESTs were able to provide the linguistic model for students, especially in terms of pronunciation and oral language proficiency. Further, NESTs were good sources of information concerning the cultural dimensions of the English language. Therefore, the combination of both NESTs and NNESTs will maximize the strengths of both NESTs and NNESTs.

\section{Methodology}

\section{Participants}

The participants of the present study were seventeen Indonesian teachers who were teaching English in different provinces in Thailand. The seventeen participants consisted of fifteen female teachers and two male teachers. All of the participants have earned a bachelor's degree in English Language Teaching (ELT). Most of the participants were assigned to teach English at primary schools in Thailand, which cover different English subjects, such as Phonics, English for Communication, English Basic, Speaking and Listening, Writing and Reading, and General English. However, the researcher found out that in addition to teaching English, three participants were also assigned to teach other subjects such as Math, Science, and Social.

The cities and provinces where the Indonesian EFL teachers worked were varied and mostly located outside the capital city of Thailand. Twelve participants worked in the northeast of Thailand, in provinces such as Amnat Charoen, Ubon Ratchathani, Buriram, and Mahasarakham. Three participants worked in the northern cities in Thailand, namely Chiang Rai and Lampang. Lastly, two participants worked in a city located in the north of Bangkok, namely Ayutthaya. The details of the participants' information are presented in table 1. 
Table 1. The Participants' Information

\begin{tabular}{|c|c|c|c|c|c|c|}
\hline Participants & Province & Age & Gender & $\begin{array}{l}\text { Educational } \\
\text { Background }\end{array}$ & $\begin{array}{c}\text { Years of } \\
\text { Teaching in } \\
\text { Thailand }\end{array}$ & Subjects \\
\hline 1 & Buriram & 27 & Female & $\begin{array}{l}\text { Bachelor's } \\
\text { degree in } \\
\text { ELT } \\
\end{array}$ & 7 months & English \\
\hline 2 & $\begin{array}{l}\text { Amnat } \\
\text { Charoen }\end{array}$ & 26 & Female & $\begin{array}{l}\text { Bachelor's } \\
\text { degree in } \\
\text { ELT }\end{array}$ & 1 year & $\begin{array}{l}\text { Phonics } \\
\text { English for } \\
\text { Communication } \\
\text { English Basic }\end{array}$ \\
\hline 3 & Ayutthaya & 25 & Female & $\begin{array}{l}\text { Bachelor's } \\
\text { degree in } \\
\text { ELT }\end{array}$ & 1 year & $\begin{array}{l}\text { English for } \\
\text { Communication }\end{array}$ \\
\hline 4 & Mahasarakham & 24 & Male & $\begin{array}{l}\text { Bachelor's } \\
\text { degree in } \\
\text { ELT }\end{array}$ & 1.7 years & $\begin{array}{l}\text { English for } \\
\text { Communication }\end{array}$ \\
\hline 5 & Buriram & 27 & Female & $\begin{array}{l}\text { Bachelor's } \\
\text { degree in } \\
\text { ELT }\end{array}$ & 7 months & General English \\
\hline 6 & Lampang & 26 & Male & $\begin{array}{l}\text { Bachelor's } \\
\text { degree in } \\
\text { ELT } \\
\end{array}$ & 2 years & $\begin{array}{l}\text { Speaking and } \\
\text { Listening } \\
\text { Writing and Reading }\end{array}$ \\
\hline 7 & $\begin{array}{l}\text { Pakham, } \\
\text { Buriram }\end{array}$ & 27 & Female & $\begin{array}{l}\text { Bachelor's } \\
\text { degree in } \\
\text { ELT }\end{array}$ & 8 months & $\begin{array}{l}\text { Listening and } \\
\text { Speaking }\end{array}$ \\
\hline 8 & $\begin{array}{l}\text { Amnat } \\
\text { Charoen }\end{array}$ & 26 & Female & $\begin{array}{l}\text { Bachelor's } \\
\text { degree in } \\
\text { ELT } \\
\end{array}$ & 1 year & $\begin{array}{l}\text { English for } \\
\text { Communication } \\
\text { Science }\end{array}$ \\
\hline 9 & $\begin{array}{l}\text { Amnat } \\
\text { Charoen }\end{array}$ & 26 & Female & $\begin{array}{l}\text { Bachelor's } \\
\text { degree in } \\
\text { ELT }\end{array}$ & 1 year & $\begin{array}{l}\text { General English } \\
\text { Mathematics }\end{array}$ \\
\hline 10 & Chiang Rai & 23 & Female & $\begin{array}{l}\text { Bachelor's } \\
\text { degree in } \\
\text { ELT }\end{array}$ & 1.2 years & $\begin{array}{l}\text { English for } \\
\text { Communication } \\
\text { Reading and Writing }\end{array}$ \\
\hline 11 & $\begin{array}{l}\text { Ubon } \\
\text { Ratchathani }\end{array}$ & 25 & Female & $\begin{array}{l}\text { Bachelor's } \\
\text { degree in } \\
\text { ELT } \\
\end{array}$ & 1.5 years & $\begin{array}{l}\text { General English } \\
\text { Science } \\
\text { Social } \\
\end{array}$ \\
\hline 12 & Ayutthaya & 26 & Female & $\begin{array}{l}\text { Bachelor's } \\
\text { degree in } \\
\text { ELT } \\
\end{array}$ & 1 year & General English \\
\hline 13 & $\begin{array}{l}\text { Amnat } \\
\text { Charoen }\end{array}$ & 25 & Female & $\begin{array}{l}\text { Bachelor's } \\
\text { degree in } \\
\text { ELT }\end{array}$ & 1.5 years & $\begin{array}{l}\text { English Basic } \\
\text { Phonics }\end{array}$ \\
\hline 14 & Chiang Rai & 26 & Female & $\begin{array}{l}\text { Bachelor's } \\
\text { degree in } \\
\text { ELT }\end{array}$ & 1 year & $\begin{array}{l}\text { Phonics } \\
\text { General English }\end{array}$ \\
\hline 15 & $\begin{array}{l}\text { Amnat } \\
\text { Charoen }\end{array}$ & 27 & Female & $\begin{array}{l}\text { Bachelor's } \\
\text { degree in } \\
\text { ELT }\end{array}$ & 2 years & $\begin{array}{l}\text { Phonics } \\
\text { English Basic } \\
\text { English for } \\
\text { Communication }\end{array}$ \\
\hline 16 & $\begin{array}{l}\text { Ubon } \\
\text { Ratchathani }\end{array}$ & 27 & Female & $\begin{array}{l}\text { Bachelor's } \\
\text { degree in } \\
\text { ELT }\end{array}$ & 1 year & $\begin{array}{l}\text { English for } \\
\text { Communication }\end{array}$ \\
\hline
\end{tabular}




\begin{tabular}{|c|c|c|c|c|c|c|}
\hline 17 & $\begin{array}{l}\text { Ubon } \\
\text { Ratchathani }\end{array}$ & 25 & Female & $\begin{array}{l}\text { Bachelor's } \\
\text { degree in } \\
\text { ELT }\end{array}$ & 2 years & $\begin{array}{l}\text { General English } \\
\text { Science } \\
\text { Social }\end{array}$ \\
\hline
\end{tabular}

\section{Data Collection}

In order to collect the data about the challenges and experiences faced by Indonesian EFL teachers in Thailand, the present study employed a questionnaire and interviews. The questionnaire items were modified and adapted from Ulla (2019) and aimed at discovering the demographic data of the participants and exploring their experiences and challenges during a teaching in Thailand. However, the dimensions of the questionnaire employed in the present study have been adjusted with the relevant contexts of the participants of the present study. The questionnaire used in the present study consists of three dimensions, namely purposes, school environments, and problems, and conflicts.

The questionnaire consisted of closed-response items about participants' experiences and challenges, which ranged from strongly disagree (1), disagree (2), undecided (3), agree (4), and strongly agree (5). Then the questionnaire was distributed to the seventeen participants by using Google Form. Since the present study did not include a large number of participants, the data analysis from the questionnaire was done manually by counting the number of participants who select particular scales. Then, the researcher was the one who qualitatively interpreted the data. This step is done because, in qualitative research, the researcher is the primary instrument for data collection and analysis (Merriam, 2009).

In order to gather more abundant data and details about the experiences and challenges faced by Indonesian EFL teachers in Thailand, semi-structured interviews were delivered to four participants who were teaching at four different schools in Thailand. Besides, the interview was done to clarify some points related to the questionnaire items. The interview questions were developed by the researcher. They consisted of ten questions about the experiences and challenges of the Indonesian EFL teachers in Thailand, especially the ways the Indonesian EFL teachers deal with culture, school environments, school staff, Thai teachers, other foreign teachers, and problems in the English classes. The interviews were conducted both in English and Bahasa Indonesia and were done twice during the weekends.

In the present study, both questionnaires and interviews were used to enhance the validity and reliability of the study. The researcher followed the methodological triangulation, namely between-method triangulation in which the researcher made use of multiple sources of data collections (Denzin, 1978). The data obtained from one instrument was compared to the data gathered from another instrument. For instance, the data gathered from the questionnaire were compared to the data collected from the interview to see if they corroborated. 


\section{Results and Discussion}

\section{Results}

The data gathered from the questionnaire and interview about the experiences and challenges of the Indonesian EFL teachers in Thailand are classified into three dimensions, namely purposes, school environments, and problems and conflicts. The first dimension, which is the purpose, covers the reasons for the Indonesian EFL teachers for teaching English in Thailand. The second dimension, which is the school environment, covers the situations faced by the Indonesian EFL teachers in dealing with people with a different culture, such as the students and the school staffs. The third dimension, which is the conflicts, covers the issues faced by the Indonesian EFL teachers in Thailand.

\section{Purposes}

Chart 1. Reasons to Teach English in Thailand

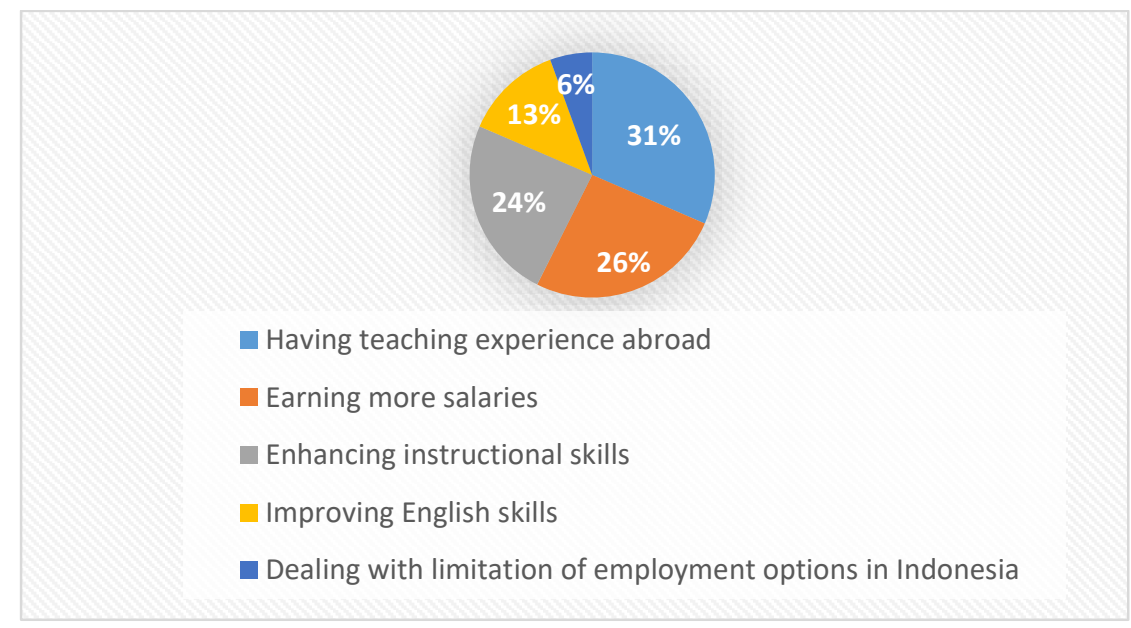

Based on the questionnaire illustrated in Chart 1, the researcher discovered that there were several reasons of the Indonesian EFL teachers to teach English in Thailand, such as for having teaching experience abroad, earning more salaries, enhancing instructional skills, having improvements in English skills, dealing with the limitation of the employment options in Indonesia, and learning another school curriculum. However, for most of the participants, having the teaching experience abroad was still the main reason. Meanwhile, the least reason behind the Indonesian EFL teachers' decision to teach English in Thailand was to learn another school curriculum.

Meanwhile, from the interview, two of the Indonesian EFL teachers reported their reasons for teaching English in Thailand as follows:

Participant 1: 
I decide to come to Thailand and teach here because I want to have experiences of teaching abroad. I think by teaching abroad my English skill will improve and my knowledge can be practically implemented.

Participant 2:

Basically I come from a remote area in Indonesia. I feel that being able to work abroad is cool. The salary is also good for a fresh graduate like me. It is better than the salary for a fresh graduate in Indonesia.

\section{School Environments}

Table 2. Culture and School Environment

\begin{tabular}{|c|c|c|c|c|c|}
\hline \multirow{2}{*}{ Statements } & \multicolumn{5}{|c|}{ Numbers of Participants } \\
\hline & $\begin{array}{l}\text { Strongly } \\
\text { Disagree }\end{array}$ & Disagree & Undecided & Agree & $\begin{array}{l}\text { Strongly } \\
\text { Agree }\end{array}$ \\
\hline $\begin{array}{l}\text { At my school, all local teachers, including the } \\
\text { staff respect all races and cultures }\end{array}$ & - & 1 & 1 & 8 & 7 \\
\hline $\begin{array}{l}\text { The administrators always have a fair and equal } \\
\text { treatment to all foreign teachers. }\end{array}$ & 1 & 1 & 2 & 8 & 5 \\
\hline $\begin{array}{l}\text { I do not have a hard time adjusting to the } \\
\text { culture of Thailand. }\end{array}$ & - & 1 & 1 & 8 & 7 \\
\hline $\begin{array}{l}\text { I do not have a hard time adjusting to the new } \\
\text { teaching environment. }\end{array}$ & 2 & 9 & 4 & 1 & 1 \\
\hline $\begin{array}{l}\text { The school provides training and other } \\
\text { professional development for all teachers. }\end{array}$ & 2 & 8 & - & 3 & 4 \\
\hline $\begin{array}{l}\text { My school provides teaching materials to be } \\
\text { used in class. }\end{array}$ & - & 1 & 1 & 12 & 3 \\
\hline $\begin{array}{l}\text { I always get support from my local Thai partner } \\
\text { teacher. }\end{array}$ & - & 3 & 2 & 11 & 1 \\
\hline $\begin{array}{l}\text { I do not feel any discrimination in any form in } \\
\text { the school }\end{array}$ & - & - & 3 & 8 & 6 \\
\hline $\begin{array}{l}\text { Sometimes, my skill is compared to other } \\
\text { foreign teachers, especially those from } \\
\text { English-speaking countries }\end{array}$ & 2 & 7 & 4 & 4 & - \\
\hline $\begin{array}{l}\text { Whenever there is an event in the school, the } \\
\text { Indonesian teachers are always informed and } \\
\text { invited. }\end{array}$ & - & 4 & 3 & 5 & 5 \\
\hline $\begin{array}{l}\text { The school provided me with proper } \\
\text { orientation to the teaching that I will be doing, } \\
\text { and to the environment where I will be } \\
\text { working. }\end{array}$ & - & 8 & 1 & 2 & 6 \\
\hline $\begin{array}{l}\text { The school provides me with benefits on top of } \\
\text { my salary. }\end{array}$ & - & 5 & 4 & 7 & 1 \\
\hline $\begin{array}{l}\text { My salary now is lower than the native English } \\
\text { teachers teaching in my school. }\end{array}$ & - & 3 & 2 & 3 & 9 \\
\hline $\begin{array}{l}\text { My salary now is lower than other foreign } \\
\text { teachers teaching in my school. }\end{array}$ & 2 & 2 & 3 & 5 & 5 \\
\hline $\begin{array}{l}\text { If I would assess my teaching experience here, } \\
\text { I would say that it met my expectations. }\end{array}$ & 2 & 3 & 6 & 6 & - \\
\hline
\end{tabular}




$\begin{aligned} & \text { I hope to continue teaching in Thailand for } \\ & \text { more years. }\end{aligned}$
$\begin{aligned} & \text { I would encourage a friend in Indonesia to } \\ & \text { come to Thailand and teach. }\end{aligned}$

In addition to the reasons to teach English in Thailand, participants were also asked about their experiences as foreign teachers who had to deal with a new school environment and with the school staffs who came from different backgrounds and cultures. From the data gathered from the questionnaire, despite the differences in cultures between Indonesia and Thailand, almost all local teachers in Thailand respected all races and cultures. Besides, most of the school administrators had a fair and equal treatment to all foreign teachers. The detail perception was described in table 1 above.

In the interviews conducted, teachers made these comments:

Participant 2:

I feel comfortable to make friends with everyone. Everyone is nice, and I am close enough with Thai teachers here, especially the male teachers. We even play football together after the school hours.

Participant 4:

Since I am still a new teacher, I can't speak Thai. So whenever I talk to the Thai teachers, they run because maybe they don't understand what I say. But I think they are actually friendly. I usually talk with the staff at the administration room, to English teachers and to the school director. Because of the limitation of the language, sometimes misunderstanding happens, but I think everyone treats me well, so I don't have reasons to feel discriminated.

It should be noted that most of the Indonesian teachers participating in this study had a hard time adjusting to the new teaching environment. Besides, not all schools provided teachers with training and other professional developments. Ten Indonesian EFL teachers did not get any training and other professional developments. Meanwhile, seven Indonesian EFL teachers stated that they joined the training and other professional development from the school.

However, in terms of teaching materials, fifteen teachers agreed that the schools provided them with teaching materials to be used in the classrooms. Further, in terms of orientation before teaching, only eight teachers got proper orientation to the teaching environment. Meanwhile, from the interview, two of the participants reported the experiences related to the culture and teaching environment and follows:

Participant 3: 
Although the cultures of Indonesia and Thailand are not so much different, at first I find the difficulty to adjust with the Thai culture. For example, I used to do the handshake when I meet new people, but in Thailand we don't do that. And I also don't know that we respect people who have higher level than us that way.

My school is actually a new school in the province, but the English teachers were provided me with quite complete English textbooks, posters, and flashcards. The books are well known and published by international publishers. Also, on the first two days of my working day at my school, all of the English teachers got workshops about how to use the books to teach English. I don't know if that experience can be counted as orientation or not.

\section{Participant 4:}

I don't feel any difficulties in adjusting with the environment. I think Thais and Indonesians are almost similar in the way of behaving. I can adapt to the environment quickly too. But at school, there was a tendency of misunderstanding because sometimes teachers didn't share the important information. And for the training, I did not get any training before teaching at the school. When I came to the school for the first time, the coordinator of English just asked me to focus on listening and speaking. The Thai English teachers showed me the books they used for teaching English, then I tried to prepare worksheets for teaching by myself. I just follow the topics from the books.

Although there were differences in cultures and languages used by the Indonesian EFL teachers and other local Thai teachers, the local Thai teachers helped the majority of the participants (twelve teachers) sincerely. Two participants reported the way they mingled with the Thai teachers as follows:

\section{Participant 1:}

I don't know if this is just my personal experience. The Thai teachers are actually kind and friendly. In my opinion, in the classroom, Thai teachers are helpful but only for the kindergarten teachers. But personally I have no problems with that because when I am the only teacher in the classroom, I can develop my own skill.

Participant 3:

If it is about the homeroom teachers, I would say that they are very helpful. Some of the homeroom teachers help me a lot in the classroom. They don't understand English, but they always ask students to be quiet and listen to me 
when I am teaching. Since I rarely collaborate with the Thai English teachers, I think they are also helpful in different contexts. We just work together when there are English events or English competitions at school.

It is important to note that in terms of the teaching skills, the majority of the participants stated that the skill of Indonesian EFL teachers was not compared to other foreign teachers, especially those from the English-speaking countries. Meanwhile, four teachers were not sure about it. Lastly, four teachers specified that their skills were compared to other foreign teachers from the English-speaking countries.

\section{Participant 3:}

In my case, I haven't got any experiences of being compared with other foreign teachers. However, once, the foreign teachers from the Englishspeaking countries supervised me in teaching.

In terms of compensations, eight teachers reported that they were provided with benefits on top of their salary. Meanwhile, four teachers were unsure about the statement, and five other teachers disagreed that the school provided them with benefits on top of their salary. Moreover, nine Indonesian EFL teachers strongly agreed that their salary was lower than the native English teachers teaching at their school. Besides, three teachers also agreed to the statement. Meanwhile, two teachers neither agreed nor disagreed since they did not know the salary of other teachers. Lastly, three Indonesian EFL teachers disagreed with the statement because, according to them, their salary was higher than the native English teacher's teaching in their school. Nonetheless, in terms of comparison between the salary of Indonesian EFL teachers and other foreign teachers, the majority of the Indonesian EFL teachers agreed that their salary was lower than the foreign English teachers teaching at their school.

\section{Participant 1:}

My salary is less than the salary of the foreign teachers who come from the English-speaking countries. Yeah maybe because the school sees the foreigners as the real English users. The school also uses them for branding since the school believes that the parents will trust schools which have foreigners, especially those who are from the western countries.

\section{Participant 2:}

I know that my salary is almost the same as what the Thai teachers got. My salary is lower than the salary of other foreign teachers from the Englishspeaking countries. But I got more benefits like a room to stay, meals from Monday to Friday, and the school pays for my visa. So I am okay with that. 
Surprisingly, only six participants agreed that their teaching experience in Thailand met their expectations. Hence, only three of seventeen participants were assured to continue teaching in Thailand for more years. Nevertheless, six participants were unable to decide yet, and the last eight participants had no expectation of continuing their teaching in Thailand. In addition, eleven participants would be pleased to encourage their friends in Indonesia to come to Thailand and teach, while five other participants were unable to decide yet. At this point, none of the participants who neglected to encourage their friends to come to Thailand and teach.

Participant 1:

I am happy that I am here. Now I am just thinking about working here, saving money, improving my skills, and gaining more experiences. I still cannot decide to come back to Indonesia, especially because now many more Indonesian friends become English teachers in Thailand. So, I would say to them that they may also come to Thailand and teach.

Participant 2:

I have been comfortable with the school environment, especially my colleagues. Actually, I am responsible for teaching 26 periods per week, which are tiring. But I am fine with that because the teaching materials are not too difficult. I am also happy with the salary. I really understand that my salary is smaller than teachers from other countries, but I get many facilities, such as meals for three times a day from Monday to Friday. I also get extra money for my meals for the weekend. The school even pays for my visa and I do not need to rent it outside the school because the school prepares a room for me. Since I am a fresh graduate, I think I receive enough from the school.

\section{Problems and Conflicts}

From the questionnaire, the researcher discovered that there were several problems faced by the Indonesian EFL teachers teaching English in Thailand, such as students' motivations, linguistic gaps, and plagiarisms. 
Chart 2. Problems and Conflicts

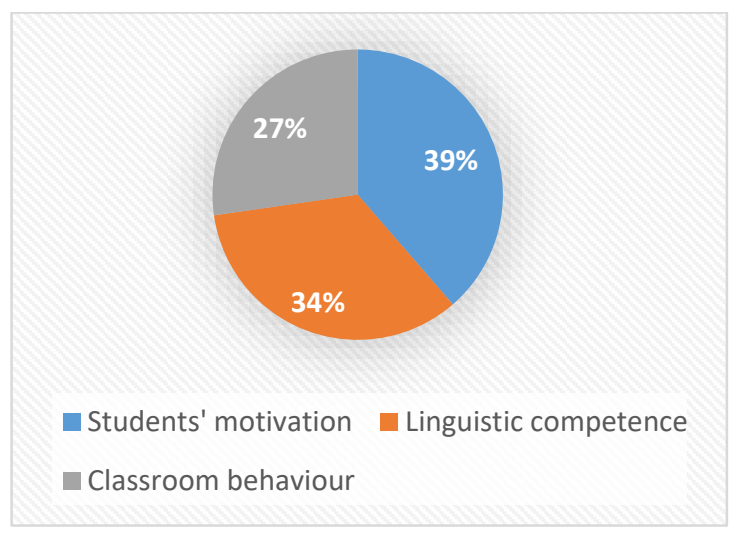

Based on Chart 2 above describes that although the majority of the participants agreed that students in Thailand respected them as Indonesian English teachers, there were different points of view in terms of students' motivation. Two participants expressed their points of view on students' motivations as follows.

\section{Participant 3:}

I think the students have different level of motivation. I teach four different levels of students, and in each class I find three or four students who were very demotivated in learning English. There are still many students who are very interested in learning English, so I'm okay with that. I just want to be more creative in teaching so that they can have more motivation in learning English.

\section{Participant 4:}

I think students respect me as their teachers, but they don't do it the same way as they respect the Thai teachers. I can understand that students are not afraid of me since I never hit them. What I cannot tolerate is the troublemakers in the class who don't listen to me. Also, there are students who sometimes don't do what I ask them to do. They don't do the homework that I give to them, but they always do what the Thai teachers ask them to do. Maybe some of them are motivated to learn English, but some others are not.

The Indonesian EFL teachers also discovered some linguistics issues. Firstly, students were lack of English vocabulary. Secondly, in learning English, students really were greatly influenced by their mother tongue. The last issue was that students did not show a good understanding of the teacher's use of phrases. Therefore, almost all participants specified that they had a hard time dealing with students. As a result, there were some actions taken by the teachers. Despite the fact that all participants were assigned to deliver the lessons in English, most of the participants decided to 
learn and use the local language to facilitate a better understanding in the classroom. Despite the difficulties, the majority of the participants agreed that they had confidence in their ability to teach English to Thai students.

\section{Participant 2:}

The majority of my students cannot speak English because there are lack of vocabulary. It is also difficult for them to understand since they haven't had the logic about English language which is very different from their language. The letters are different. The sounds are also different. So, students tend to misunderstand my instruction.

\section{Participant 3:}

Many students always use Thai, even in English classes. It was difficult for me to understand them so I learned some Thai phrases and tried to speak Thai as well. I know that it was wrong to speak Thai to warn students to ask them to listen to me in English classes. But sometimes I don't have other solutions for students who don't want to listen to my lesson.

The experiences of the Indonesian EFL teachers in Thailand also covered the actions to deal with problems and conflicts. The data gathered from the questionnaire about the experiences in dealing with problems and conflicts are stated in Table 3.

Table 3. Dealing with Problems and Conflicts

\begin{tabular}{|c|c|c|c|c|c|}
\hline \multirow{2}{*}{ Statements } & \multicolumn{5}{|c|}{ Numbers of Participants } \\
\hline & $\begin{array}{l}\text { Strongly } \\
\text { Disagree }\end{array}$ & Disagree & Undecided & Agree & $\begin{array}{l}\text { Strongly } \\
\text { Agree }\end{array}$ \\
\hline $\begin{array}{l}\text { I am learning and using the local language to } \\
\text { facilitate a better understanding in the } \\
\text { classroom. }\end{array}$ & - & - & 3 & 9 & 5 \\
\hline $\begin{array}{l}\text { I have confidence in my ability to teach English } \\
\text { to Thai students. }\end{array}$ & - & - & 2 & 6 & 9 \\
\hline $\begin{array}{l}\text { I employ interactive activities, games and other } \\
\text { child-centred strategies in my teaching. }\end{array}$ & - & - & 1 & 6 & 10 \\
\hline $\begin{array}{l}\text { I always make my English classroom a fun } \\
\text { place to learn English. }\end{array}$ & - & - & 3 & 5 & 9 \\
\hline $\begin{array}{l}\text { My experience as an EFL teacher in this school } \\
\text { has been positive so far. }\end{array}$ & - & - & 5 & 6 & 6 \\
\hline
\end{tabular}

The majority of the participants (fifteen participants) stated that they were confident with their ability to teach English to Thai students. Therefore, to deal with the condition, fourteen participants learn and use the local language to facilitate a better 
understanding of the classroom. More importantly, as English teachers, the majority of the participants (sixteen participants) specified that they employed interactive activities, games, and other child-centered strategies in their teaching. To be more specific, fourteen participants stated that they always made the English classroom a fun place to learn English. As a result, the twelve participants agreed that their experiences as Indonesian EFL teachers in Thailand were positive.

\section{Discussion}

Based on the data gathered from the questionnaire and interview, there are valuable experiences and challenges faced by Indonesian EFL teachers in Thailand. The findings have highlighted some points of discussion.

Firstly, in terms of purposes to teach English in Thailand, the study finds out that most of the Indonesian EFL teachers want to have teaching experience abroad. It follows that by teaching abroad, the Indonesian EFL teachers want to improve their English skills and practically implement their knowledge. Also, the fresh graduate teachers consider that teaching EFL in Thailand has more benefits in terms of salary compared to the salary of fresh graduate in Indonesia. The reasons are almost similar to the study conducted by Ulla (2019), which reveals that most of the participants of the study came to teach English in Bangkok primarily to support their families in the Philippines. They also believe that teaching abroad provides them with knowledge of some teaching strategies and methodologies for EFL students.

Secondly, although there are similarities and differences in cultures between Indonesia and Thailand, the study reveals that Indonesian EFL teachers can quickly adapt to the new culture. However, in terms of the school environment, the majority of the Indonesian teachers still had a hard time adjusting to the new teaching environment because not all schools provide teachers with training and other professional developments. These findings are inconsistent with the previous study conducted by Ulla (2019) in which more than half of the participants did not have a hard time adjusting to the new teaching environment and its culture. On the contrary, when the Indonesian EFL teachers are assigned to teach English for the first time, most schools, through the coordinator of English program, directly assign the Indonesian EFL teachers with the teaching subjects. The school also provides the Indonesian EFL teachers with teaching materials to be used in the classrooms, then asks the Indonesian EFL teachers to write and submit the lesson plan for one semester.

Regarding the issues of a dichotomy of NNESTs over the NESTs, the study is inconsistent with the previous studies (Braine, 2010; Walkinshaw \& Oanh, 2014). The Indonesian EFL teachers have never experienced discriminations since both NESTs, and NNESTSs are treated fairly and equally by the school staffs and administrators. In addition, whenever there was an event held in school, most of Indonesian EFL teachers 
agreed that they were invited to every event held in school. Thus, the Indonesian EFL teachers and other foreign teachers work together and involve in all activities.

Nevertheless, although in terms of benefits, the Indonesian EFL teachers received excellent salaries and other facilities, their salary was lower than the native English teachers teaching at their school. Other studies (Hickey, 2014; Ulla, 2019) have also presented the fact that NNESTs consistently receive the lowest salaries, despite the fact that many of them are highly qualified and have considerable experience. Ulla (2019) also categorizes unequal salaries as a form of discrimination since both NESTs and NNESTs do the same work. However, the Indonesian EFL teachers in Thailand perceive their salaries as enough compensation for their work, and they still prefer to teach English in Thailand since the salaries are much better than what they receive in Indonesia. Thus, although most of the participants stated that their teaching in Thailand did not meet their expectations, they still wanted to continue teaching in Thailand for more years. They would also be pleased to encourage their friends in Indonesia to come to Thailand and teach.

The third point to note is the problems and conflicts faced by Indonesian EFL teachers in Thailand. Although, in terms of respect, students in Thailand respected the Indonesian English teachers, the study revealed other issues in the English classroom. The first is such as students' motivations, linguistic gaps, and plagiarisms. In all schools, there were two kinds of students. Many students were highly motivated, but some others were not since they could not find the importance of learning English. This fact is in line with Chamcharatsiri (2010), which revealed that Thai students still claimed that English subject was monotonous and stressful, and they did not even find reasons to learn English. Meanwhile, (Grubbs, et al., (2009) revealed that students had positive views on English. Thus, in order to solve the problems, the study also showed that the Indonesian EFL teachers tried to use creative methods so that students were motivated to learn English.

In addition, the Indonesian EFL teachers also discovered some linguistics issues. It is essential to note that the crucial linguistic problem is that the majority of the students are lack of English vocabulary. Therefore, students do not show a good understanding of the teacher's use of phrases. The three linguistics issues are experienced by almost all Indonesian EFL teachers participating in this study although English has been a part of the curriculum and becomes a compulsory subject from primary school onward in Thailand (Chamcharatsiri, 2010), and its presence in formal schools has been for around 150 years (Grubbs et al., 2009).

Furthermore, the study revealed that almost all participants found out that students had difficulty understanding their lesson due to the significant influence of the mother tongue. Students found problems in pronouncing some words ending, writing alphabets, and understanding grammatical structure. Thus, the participants decided to learn and use the local language to facilitate a better understanding of the students in the classroom. This finding is in line with Minegishi (2011) that states that 
the Thai language is somehow different from English in terms of phonological, grammatical, and lexical items. Besides, in terms of speech or expression, Thai people have less explicit strategies (Intachakra, 2004).

Lastly, the participants agreed that their experience as Indonesian EFL teachers in Thailand was positive. They learned a lot to improve their instructions and be more creative and innovative. The study also discovered that in terms of activities in the classroom, all of the participants specified the needs of interactive activities, games, and other child-centered strategies in their teaching. They tried to make the English class a fun place to learn English since they expected that all students would be interested in the lessons.

\section{Conclusion}

To sum up, at some points, the results of this study are consistent with other previous studies on NNESTs in Thailand. In line with the experiences of NNESTs investigated in Ulla (2019), the purpose of teaching English in Thailand is to have teaching experience abroad. In addition, the participants are eager to improve their English skills and to earn higher salaries than they might make in Indonesia. Even though the participants have never experienced discriminations, they receive lower salaries than NESTs (Hickey, 2014; Ulla, 2019).

The results of the present study are inconsistent with other studies (Braine, 2010; Ulla, 2019; Walkinshaw \& Oanh, 2014) in terms of adaptation to new cultures, teaching environments, and the dichotomy of NNESTs over the NESTs. Although the study reveals issues in the English classroom such as motivations, linguistic gaps, and plagiarisms, students in Thailand still pay respect to the Indonesian English teachers. The study also shows that through the experiences of being an EFL teacher in Thailand, the Indonesian EFL teachers learn to improve their instructions and be more creative and innovative to make the English classroom a fun place to learn English.

This study is limited in terms of its subjects and context. The subjects of the study were the Indonesian EFL teachers who teach EFL in primary schools in Thailand. Therefore, other researchers may conduct further research on the experiences and challenges of a broader representation of NNESTs who come from other non-English-speaking countries and teach EFL in different circumstances. 


\section{References}

Benson, P. (2012). Learning to teach across borders: Mainland Chinese student English teachers in Hong Kong schools. Language Teaching Research, 16(4), 483. https://doi.org/10.1177/1362168812455589

Braine, G. (2010). Non-native speaker English teachers: Research, pedagogy and professional growth. London: Routledge.

Brown, H. D., \& Lee, H. (2015). Teaching by principles: An interactive approach to language pedagogy. New York: Pearson Education.

Chamcharatsiri, P. B. (2010). On teaching creative writing in Thailand. Writing on the Edge, 21(1), 18-26. https://doi.org/https://www.jstor.org/stable/43157412

Denzin, N. (1978). Sociological methods: A sourcebook. New York: McGraw Hill.

Grubbs, S. J., Chaengploy, S., \& Worawong, K. (2009). Rajabhat and traditional universities: Institutional differences in Thai students' perceptions of English. Higher Education, 57(3), 283-298. https://doi.org/10.1007/s10734-008-9144-2

Hickey, M. (2014). English for ASEAN!: African and Asian Teacher Migration in Response to Thailand's English-language Education Boom.

Intachakra, S. (2004). Contrastive pragmatics and language teaching: Apologies and thanks in English and Thai *T. RELC Journal, 35(1), 37-62. https://doi.org/10.1177/003368820403500105

Merriam, S. B. (2009). Qualitative research: A guide to design and implementation. San Francisco: Jossey-Bass.

Methanonppkakhun, S., \& Deocampo, M. (2016). Being an English language teacher: A narrative analysis of foreign teachers in Thailand. The New English Teacher, 10(1), 1-19.

Minegishi, M. (2011). Description of Thai as an isolating language. Social Science Information, 50(1), 62-80. https://doi.org/10.1177/0539018410389107

OECD-UNESCO. (2016). Education in Thailand: An OECD-UNESCO Perspective. Paris: OECD Publishing. 
Songsirisak, P. (2017). Non-native English speaking teachers: Uncovering Thai EFL teachers' instructional practices in an international program of Thai university. Journal of Education, 11(4), 125-138.

Sung, C. C. M. (2012). Non-native speaker teachers of English: Challenges and prospects - An interview with George Braine. The Language Teacher, 36(2), $23-26$.

Tanielian, A. R. (2014). Foreign language anxiety in a new English program in Thailand. International Education Journal, 13(1), 60-81.

Ulla, M. B. (2019). Filipinos as EFL Teachers in Bangkok, Thailand: Implications for Language Education Policy in the ASEAN Region. RELC Journal. https://doi.org/10.1177/0033688219879775

Walkinshaw, I., \& Duong, O. (2012). Native- and non-native speaking English teachers in Vietnam: Weighing the benefits. Tesl-Ej, 16(3).

Walkinshaw, I., \& Oanh, D. H. (2014). Native and non-native English language teachers: Student perceptions in Vietnam and Japan. SAGE Open, 4(2). https://doi.org/10.1177/2158244014534451

Waterworth, P. (2016). Teaching English in ASEAN: The voices of English teachers in ASEAN nations. Indonesian Journal of Applied Linguistics, 5(2), 154-166. https://doi.org/https://doi.org/10.17509/ijal.v5i2.1340

Young, T. J., \& Walsh, S. (2010). Which English? Whose English? An investigation of "non-native" teachers' beliefs about target varieties. Language, Culture and Curriculum, 23(2), 123-137. https://doi.org/10.1080/07908311003797627 